\title{
カチオン交換合成 $\mathbf{A}$ 型ゼオライト触媒による エチルエチレンオキシドの異性化反応 ${ }^{122}$
}

\author{
（1973 年 4 月 23 日 受理）
}

新田昌弘・松本 繁 美・青 村 和 夫*

\begin{abstract}
いろいろのカチオンで交換した合成 $\mathrm{A}$ 型ゼオライトの触媒作用を調べるため，エチルエチレンオキシ ドの異性化反応を常圧流通式装置を用い，反応温度 $220^{\circ} \mathrm{C}$ で行なった。エチルェチレンオキシドの異 性化は不可逆かつ並発的に進行し，生成物はブチルアルデヒド，クロチルアルコール，エチルメチルケ トンおよび 1-ブタノールであった。
\end{abstract}

$\mathrm{A}$ 型ぜオライトの酸性質および異性化活性は交換カチオンの種類に依存し，その活性序列は ZnA> $\mathrm{CdA}>\mathrm{MgA}>\mathrm{AgA}>\mathrm{CaA}>\mathrm{SrA}, \mathrm{LiA}>4 \mathrm{~A}, \mathrm{KA}=0$ であった。触媒活性と交換カチオンの電気陰性 度および全酸量 $\left(H_{0} \leqq+4.8\right)$ との間にはそれぞれ正の相関関係が見いだされた。生成物中のブチルア ルデヒド，クロチルフルコールとェチルメチルケトンとの比率は交換カチオンの種類によらずほぼ一定 であった。結晶構造が一部崩壞している AgA のみが他とは異なった生成物分布を示した。触媒活性お よび酸性は前処理温度が $200 \sim 450^{\circ} \mathrm{C}$ の範囲で一定であるが，上り高温では低下した。

以上の結果からA型ゼオライトの触媒活性点はカチオンに配位した水分子が分極解離することにより 生じた Brönsted 酸点であること，および生成物選択性はA型ゼオライト特有の分子フルイ効果により 決定されることを結論した。

\section{1 腥 言}

合成ゼオライトの触蝶作用についての研究は数多くなされてい るす。しかしその大部分は $\mathrm{Y}$ 型，X型ゼオライト拉よびモルデナ イトを取り报って找り，A型ゼオライトの触媒作用に関する研究 報告はきわめて少ない。その理由は $\mathrm{A}$ 型ぜオライトの細孔径は

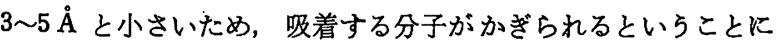
起因している。しかしA型ゼオライトは他のゼオライトにくらべ て顕著な分子フルイ作用を有するため工業的に吸着郕として広く 使用されて批り，そのため結晶满造をはじめ多くの物性が詳細化 調べられている4)。一方，この A 型ゼオライトが酸性を示すこと を考慮すれ洼固体酸の触媒作用を究明するらえに，他の固体酸触 媒より多くの利点を有している。著者らは固体酸としてのカチオ 烄换合成 $\mathrm{A}$ 型ゼオライトの触媒作用を明らかにする目的で，そ の生成物分布から触媒作用機構を知るのに有利なエチルエチンン オキシドの異性化反応について調べた。このエポキシアルカン類 の異性化反応は同様な目的からモデル反応に用いられて抒り，若 干の固体酸触媒を使用した場合の反応機構も提出されている5)。

1）本報を“合成 $\mathrm{A}$ 型ぜオライトの触媒作用に関する研究（第 2 報)”とする。

2）前報(第 1 報)，新田昌弘，田部浩三，服部英，石油誌， 15, 113(1972).

* 北海道大学工学部工業 分析化学第二䬳座, 060 札幌市北 区北 13 条西 8 丁目

3) J. Turkevich, Y. Ono, "Advances in Catalysis", Academic Press, New York, London (1969) 20, p. 135.

4）高石哲男，遊佐 厚，触媒，13，149(1971).
本研究はそれら結論を一部支持するとともに，A型ぜオライトに 特有な作用機構の存在，活性点を明らかにし，また異性化反応榊 構について若干の考察を行なった。

\section{2 実 験 方 法}

\section{1 触媒および原料}

使用した触媒は合成A型ゼオライト (Union Carbide 社製モレ キュラーシーブ $4 \mathrm{~A}$ 扎よび $5 \mathrm{~A}$ ) を母体とし母体カチオンの 5 倍当量の交換カチオンを含んた $1 \mathrm{~N}$ 塩化物水溶液（銀イオンの み硝酸塩）中で $80 \sim 90^{\circ} \mathrm{C}$ の湯浴上で 20 時間，1時間ごとによ くふりまぜながら行なったものである。この操作を 2 回行なっ

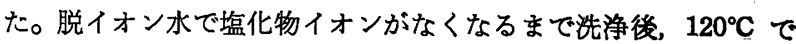
10 時間漧燥し，これを塩化アンモニウム飽和水溶液の入ったデ シケーター中に保存した。この吸湿量一定の試料を酸性質, $\mathrm{X}$ 線 回折，表面積および触媒活性測定の試料に供した。カチオンの交 換率は母体中のカチオン量とつぎのようにして求めた交換後のカ チオン量とから算出した。カチオン交換した $4 \mathrm{~A}$ ゼオライト中 に残存するナトリウム量は原子吸光分析および炎光分析により， またカチオン交換した $5 \mathrm{~A}$ ゼオライト中のカルシウム量は原子 吸光分析扣よびキレート滴定，ナトリウム量は原子吸光分析によ り測定した。測定試料は一定量のゼオライトを $1 \mathrm{~N}$ 塩酸に溶解 し、これを一定濃度に希釈して調製した。

エチルェチレンオキシド（以下 EEO と略記する）は試薬一級 品を蒸留後使用した (bp 62.4 62. $\left.9^{\circ} \mathrm{C}\right)^{6)}$ 。

5) Y. Okamoto, T. Imanaka, S. Teranishi, Bull. Chem. Soc. Jap., 45, 3251(1972). 
キャリャーガスに用いた窒素は還元銅ーケイソウ土で脱酸素し， シリカゲルで脱水精製して使用した。

\section{2 実験装置および操作法}

EEO の異性化反応は通常の常圧流通管式反応装置により行な った。内径 $10 \mathrm{~mm}$ のパイレックスガラス製反応管に 16〜20 メ ッシュに圧緶成型したゼオライト触媒 $2 \mathrm{~g}$ をつめ, 所定温度で窒 素気流中 3 時間焼成したのち, $220^{\circ} \mathrm{C}$ 前後の所定の反応温度に設 定し, EEO はマイクロフィーダーによりキャリヤーガスはオ リフィス型流量計により一定量供給して反応を開始した。生成物 および末反応原料は反応管出口で食塩-水トラッブ（-10 - 20 $\left.{ }^{\circ} \mathrm{C}\right)$ Kより捕集し，ガスクロマトグラフで分析した。カラムは acetyl tributyl citrate (10\%)-Neopak を充テンした $4 \phi \mathrm{mm} \times$ $5 \mathrm{~m}$ を用いた。

触媒活性は EEO の減少の初速度で比較した。初速度 $v_{0}$ は次 式により求めた。

$$
\begin{aligned}
& \quad v_{0}=F P \alpha / W, \mathrm{~mol} / \mathrm{g} \cdot \mathrm{hr} \\
& F: \text { 原料+キャリャーガスの供給量 }(\mathrm{mol} / \mathrm{hr}) \\
& P: \text { 原料の分压 } \\
& W: \text { 触媒重量 }(\mathrm{g})
\end{aligned}
$$

転化率ははつぎの定義にしたがった。 $\boldsymbol{\alpha}=$ 全反応生成物量 $(\mathrm{mol}) /\{$ 末反応原料 $(\mathrm{mol})$ +全反応生成物量 (mol)\}

選択性の比較はブチルアルデヒド（以下 BA と略記する）とエ チルメチルケトン（以下 MEK と略記する）の生成比で表わした。

\section{3 酸性留測定}

A型ゼオライトの酸性質は固体酸の酸性測定に用いられる通常 のアミン滴定法")により測定した。たたし，A型ゼオライトの細

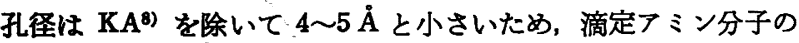
吸着平衡到達の確認に注意し，一試料の滴定には 3 4 日を費中 した。Lewis 酸点の判定には $p$-フェニレンジアミンおよびフェ ノールフタレン指示薬を用いた゚)10)。

\section{4 表面㮴测定}

BET 法にしたがって測定した。吸着質は窒素ガスを用いたが， 4 A のみ酸素ガスを用いた。カチオン交換処理前後, 焼成処理前 後および反応使用前後の試料について，それぞれ $300^{\circ} \mathrm{C}, 1$ 時間， $\sim 10^{-8}$ Torr で処理後測定した。

\section{$2.5 \mathrm{X}$ 楾回折}

粉末試料を使用し，理学電機製 ガイガーフレックス D-9 C 型 X線回折装固により，線源として $\mathrm{CuK} K_{\alpha}$ 線を用い，加速電圧 30 $\mathrm{kV}$, 龟流 $10 \mathrm{~mA}$ で測定した。カチオン交換，加熱処理および反 応使用前後の試料について測定し，これらの処理によるゼオライ

6）本実铪のガスクロマトグラフ分析では不純物は検出されな かった.

7）松崎五三男, 福田安生, 小林竜郎, 久保浩一, 田部浩三, 触媒, 11，211(1969)。

8） KA はカリウムイオン交換 $\mathrm{A}$ 型ゼオライトを表わす．とく 飞母体を明記する必要のさいは，たとえば K 5 A と略記 する.KA の細孔径は $3 \AA$ であるから指示薬すブチルフ ミンも内部表面飞吸着しないので測定不可能である.

9）奥田典夫, 日化，82，1290(1961).

10）触媒学会編，“触媒工学講座”, 地人㻎館 (1967) Vol. 4, p. 174.
トの結晶構造崩壞の程度を知る目安として主要ピークの高さを比 較した。それらのピークとして (311)，(321)，(410,322) 面のピ ークをとった。

\section{3 実験結果および考察}

\section{1 表面皘および X 線回折}

$\mathrm{AgA}$ を除いて，用いた A 型ゼオライトの表面積はカチオン交 換，焼成および反応使用前後において 606 $673 \mathrm{~m}^{2} / \mathrm{g}$ であった。 $\mathrm{AgA}$ は未処理状態で $127 \mathrm{~m}^{2} / \mathrm{g}$ であった。

$\mathrm{X}$ 線回折による主要ピーク強度は $\mathrm{Ag}$ を除き，交換カチオンの 種類によらず，また焼成処理温度 $650^{\circ} \mathrm{C}$ まで，さらに反応使用 前後ですほぽ一定であった。 $\mathrm{AgA}$ は未焼成の状態で，そのピー ク強度が母体の $5 \mathrm{~A}$ にくらべて約 $2 / 5$ に減少した。これらの結 果を表 1 に示す。

以上の表面積および X 線回折の結果から，AgA はゼオライト の結晶構造が一部破壊されていることは明らかであり，それは銀 イオン交換処理のさいに構造破壊が生じたものと思われる。その 他のカチオン交換体の結晶構造は焼成処理拐よび反応使用によっ てほとんど変化しないと思われる。

\subsection{A型ゼオライトの酸性蠋}

一般にY型， $\mathrm{X}$ 型ゼオライトは強酸点を有し，その酸量も多い ことがアミン滴定法により見いだされている11。一方，A型ゼオ ライトの酸性質については細孔径が小さいのでアミン滴定法の適 用が困難之考えられたためか報告は見あたらない。しかしアミン 滴定法の原理からす以下のように滴定に十分時間を費やせば測定 可能であることがわかった。すなわら，指示薬がゼオライトの外 部表面上の酸点に吸着し, 酸性色を示しているところへ少量のブ チルアミンを滴下すると指示薬はいったん塩基性色にすどるが， 時間の経過によりふたたび酸性色を示す。これは外部表面へいっ たん吸着したブチルアミンがゼオライト内部表面へ徐々に拡散移 行したことを示するのである。したがって吸着平衡に達するまで

Table 1 Various properties of cation exchanged Zeolites $A$

\begin{tabular}{lcccc} 
Zeolite & $\begin{array}{c}\text { Percentage } \\
\text { exchanged }\end{array}$ & $\begin{array}{c}\text { Surface } \\
\text { area }^{a)} \\
\left(\mathrm{m}^{2} / \mathrm{g}\right)\end{array}$ & $\begin{array}{c}\text { Diffrac- } \\
\text { tion } \\
\text { intensity }\end{array}$ & $\begin{array}{c}\text { Electro- } \\
\text { negativity } \\
\text { of cation }\end{array}$ \\
\hline 4 A & $(100)$ & 659 & 144 & 3.03 \\
5 A & 76 & 676 & 146 & 5.20 \\
$\mathrm{Li}$ 5 A & 69 & - & - & 2.91 \\
$\mathrm{~K}$ 5 A & 79 & - & 126 & 2.73 \\
$\mathrm{Mg}$ 4 A & 76 & - & 149 & 6.15 \\
$\mathrm{Mg} 5 \mathrm{~A}$ & 72 & 671 & 136 & 6.15 \\
$\mathrm{Ca}$ 4 A & 82 & $640^{b)}$ & 150 & 5.20 \\
$\mathrm{Ca}$ 5 A & 96 & 673 & 130 & 5.20 \\
$\mathrm{Sr} 5 \mathrm{~A}$ & 86 & - & 131 & 4.95 \\
$\mathrm{Ag} 5 \mathrm{~A}$ & 76 & 127 & 55 & 4.26 \\
$\mathrm{Cd}$ 5 A & 81 & - & 120 & 7.30 \\
$\mathrm{Zn}$ 4 A & 81 & $619^{b)}$ & 121 & 8.30 \\
$\mathrm{Zn}$ 5 A & 79 & $606^{b)}$ & 123 & 8.30
\end{tabular}

a) Calicined at $300^{\circ} \mathrm{C}$ under vacuum.

b) After reaction.

c) Sum of peak heights for (311), (321) and (410,322) planes, with constant moisture.

11）ビオライトとその利用編集委員会, “ゼオライトとその利 用”，技報堂 (1967) p. 174 . 
Table 2 Acidic properties of cation exchangted Zeolites $\mathrm{A}$

\begin{tabular}{|c|c|c|c|c|c|}
\hline \multirow[b]{2}{*}{ Zeolite $^{a)}$} & \multicolumn{5}{|c|}{ Acid amount (mmol/g) } \\
\hline & 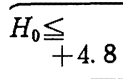 & $\begin{array}{r}H_{0} \leqq \\
+3.3\end{array}$ & $H_{0} \leqq$ & $H_{0} \leqq-3.0$ & $\overline{H_{0} \leqq}$ \\
\hline $4 \mathrm{~A}$ & 0 & 0 & 0 & 0 & 0 \\
\hline $5 \mathrm{~A}$ & 0.046 & 0.037 & 0.029 & 0.007 & 0.008 \\
\hline $\mathrm{Zn} \mathrm{A}$ & 0.140 & 0.122 & 0.100 & 0.057 & 0.043 \\
\hline $\mathrm{Mg} \mathrm{A}$ & 0.078 & 0.070 & 0.065 & 0.008 & 0.004 \\
\hline $\mathrm{CaA}$ & 0.038 & 0.029 & 0.020 & 0.006 & 0.003 \\
\hline Sr A & 0.016 & 0.014 & 0.007 & 0 & 0 \\
\hline $\mathrm{Cd} A$ & 0.121 & 0.083 & 0.084 & 0.013 & 0.009 \\
\hline $\mathrm{Li} A$ & 0.014 & 0.010 & 0.008 & 0 & 0 \\
\hline $\mathrm{KA}$ & 0 & 0 & 0 & 0 & 0 \\
\hline $\mathrm{Ag} \mathrm{A}$ & b) & b) & b) & b) & b) \\
\hline
\end{tabular}

a) Calcination temperature : $400^{\circ} \mathrm{C}, 3 \mathrm{hr}$.

b) It was impossible to determine because of its own color.

長時間を要するが，最終的には全表面の酸性質の測定は可能であ る。表 2 にアミン滴定により得られたA型ゼオライトの酸性質測 定結果を示す。交換カチオンの種類により酸性質がいらじるしく 変化していることがわかる。2 価カチオンで交換したものは SrA を除さ，酸強度 $H_{0} \leqq-5.6$ の強酸点を有し，全酸量も多いが， 1 価カチオンで交換したものは LiA のみが中程度の強さの酸点 をるっているが, $\mathrm{NaA}, \mathrm{KA}$ は弱酸点 $\left(H_{0} \leqq 4.8\right)$ もない。 $\mathrm{AgA}$ は加熱処理すると黄色に帯色するので指示薬の変色が不明膫で測 定不可能であった。

ゼオライトの酸性質については，Ward により Y 型ゼオライト について詳細に調べられている(2)19)。それによると，アルカリ土 類カチオン交換ゼオライトの表面酸性は $500^{\circ} \mathrm{C}$ 以下の焼成体では Brönsted 酸点が大部分であり，さらに高温で焼成すると Lewis 酸点を発現する。，その酸性質発現機構はカチオンに配位した水分 子 (吸着水) がカチオン場の分極作用で解離し, 放出されたプロ トンが近傍の格子酸素に付加し，Brönsted 酸点を形成する。そ して，より高温ではこれらの配位水酸基と構造水酸基が縮合脱水 除去されるため，カチオン自身，および三配位の格子アルミニウ ムが Lewis 酸点を形成するものと考えられている。本研究の場 合，焼成温度が $400^{\circ} \mathrm{C}$ なので $\mathrm{Y}$ 型と同様な酸性発現機構を仮定 すれば，A型ゼオライトの酸点の大部分は Brönsted 酸点である と推定される。この推定の妥当性を確かめるため $400^{\circ} \mathrm{C}$ おび $600^{\circ} \mathrm{C}$ で焼成した $\mathrm{ZnA}$ について $p$ ーフェレンジアミンおよび フェノールフタレン指示薬を用いて酸点の識別を行なった。 600 ${ }^{\circ} \mathrm{C}$ 焼成体はともに Lewis 酸点の存在を示す呈色 ${ }^{9) 10)}\left(p-{ }_{ \pm}=\right.$ レンジアミン：黄色から黒紫色へ，フェノールフタレン：赤色） があったが， $400^{\circ} \mathrm{C}$ 焼成体はともにほとんど呈色しなかった。こ の結果は簡便法ではあるが上に述べた推定を強く支持するすので ある。

一方，A型ゼオライトの酸性は交換カチオンの電気陰性度と密 接な関係を有することが示唆されている2)。そこで本研究に用い た $\mathrm{A}$ 型ゼオライトの全酸量（ $\left.H_{0} \leqq+4.8\right)$ と交換カチオンの電気 陰性度 ${ }^{14)}$ との関係をみると, 図 1 に示されるように雨者間には直 線関係が存在することが見いだされた。すなわち，カチオンの電

12) J. W. Ward, J. Catal., 10, 34(1968).

13) J. W. Ward, ibid., 14, 365(1969).

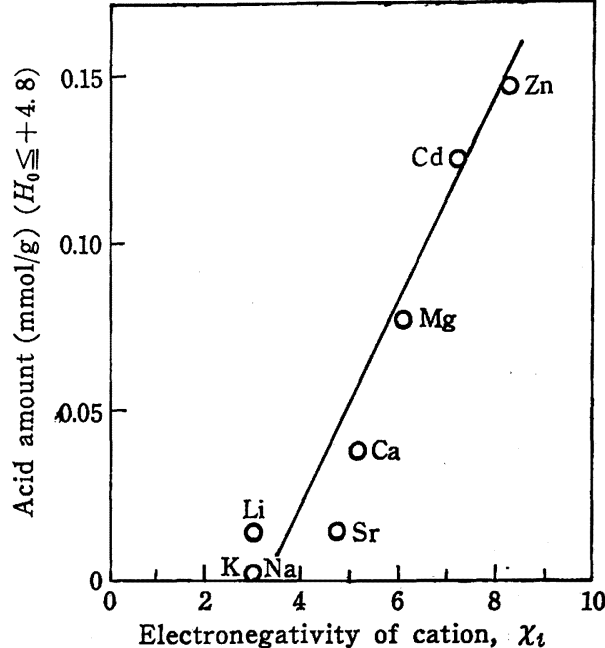

Fig. 1 Relation of acid amount of Zeolites A with electronegativity of cation

Calcination temperature $: 400^{\circ} \mathrm{C}$

気陰性度が大きいほどカチオンが水分子を分極するかが増し，配 位水分子のプロトンが放出されやすくなり酸量が増大するすのと 考えられる。したがってこの関係からも交換カチオンの配位水が 分極解離することにより生じたプロトンがA型ゼオライトの酸点 であると推定することはきわめて妥当である。

\section{3 物移動に対する検討}

触媒を使用しない場合の哄性化反応は $400^{\circ} \mathrm{C}$ まで起きなかっ たが, $450^{\circ} \mathrm{C}, F=1.58 \mathrm{~mol} / \mathrm{hr}$ の条件で微量のブチルアルデヒド の生成が認められた。触媒を使用すると反応温度 $180^{\circ} \mathrm{C} て ゙$ 異珄 化反応は容易に進行し，生成物として，ブチルアルデヒド（以下 $\mathrm{BA}$ と略記する), エチルメチルケトン (MEK), クロチルアルコ ール (CA) および 1-ブタノール (NB) が得られた。反応温度 $240^{\circ} \mathrm{C}$ 以上では生成物中に微量の水が検出された。

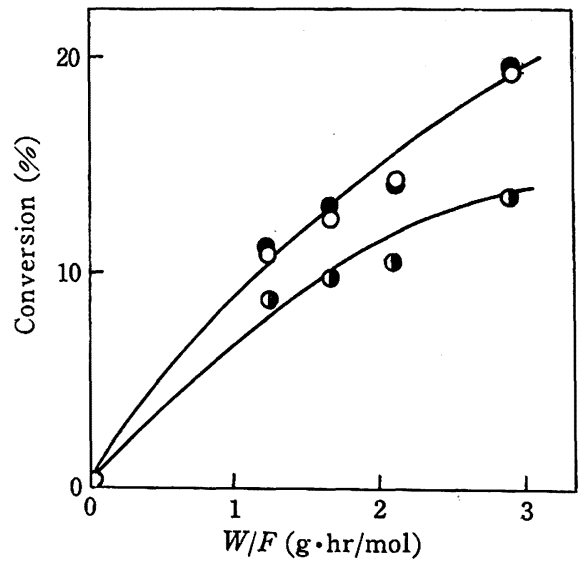

Fig. 2 Effect of external diffusion

Catalyst: $\mathrm{Mg} \mathrm{A}$, Reaction temperature : $220^{\circ} \mathrm{C}$

$W:$ Weight of catalyst

$F:$ Flow rate of EEO and carrier gas

$: 2 \mathrm{~g}, \bigcirc: 1 \mathrm{~g}, \bigcirc: 0.5 \mathrm{~g}$

14）中性原子の電気陰性度としての Allred，Rochow の電気 陰性度を採用した。 
反応時間因子 $W / F$ を一定にたるち，Wおよび $F$ をそれぞれ 変化させることにより反応速度に対する外部拡散の影響を調べた 耛果を図 2 に示す。この結果から以下の実験に扎いてWは $1.0 \mathrm{~g}$ 以上 $F$ は $0.3 \mathrm{~mol} / \mathrm{hr}$ 以上とした。内部拡散の影響は小粒径 (16 〜20メッシュ）の触媒を用いることにより無視できるすのとし た。また逆湿合の影㗽は細長い管型反応器（内径/長さ $=10 \mathrm{~mm} /$ $300 \mathrm{~mm}$ ) を用いたので無視できるものとした。

\section{4 媒の焼成温度の影㳅}

A型ゼオライトの触媒活性と焼成温度との関係を $\mathrm{CaA}$ および MgA を用いて調べた。CaA の場合の結果を図 3に示す。烧成温 度 $200 \sim 450^{\circ} \mathrm{C}$ の範囲では触媒活性は一定であるが，より高温処 理の化媒の活性は徐↔に低下する。また焼成温度の酸量 $\left(H_{0} \leqq\right.$ +4.8）に対する影暗す調べたが $200 〜 450^{\circ} \mathrm{C}$ でほぼ一定であっ た。MgA Kついてもまったく同様な結果が得られた。したがっ てA翌ゼオライトの活性点は $200 \sim 450^{\circ} \mathrm{C}$ 焼成体では同一種のも

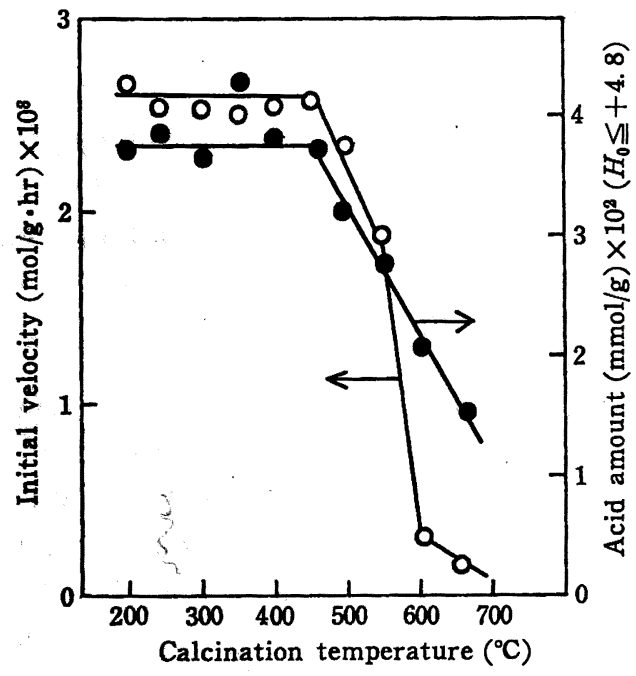

Fig. 3 Effect of calcination temperature of Zeolite A for catalytic activity

Catalyst : CaA, Reaction temperature : $220^{\circ} \mathrm{C}$, $W / F: 1.27 \mathrm{~g} \cdot \mathrm{hr} / \mathrm{mol}$
のであると考えられる。3.2 で述べたように焼成温度 $400^{\circ} \mathrm{C}$ ま でのゼオライトの酸性は Brönsted 酸点によることがわかったの で，EEO の異性化反応は Brönsted 酸点により触媒作用を受け ていると考えられる。

\section{5 触媒活性と酸性買との関係}

3.4 の結果から $400^{\circ} \mathrm{C}$ で烧成した各種カチオン交换 A 㤠ゼオ ライト触媒の活性比較を行なった結果を表 3 に示す。この結果か ら交換カチオンの種類により触媒活性がいちじるしく变化してい ることがわかる。このような活性の差異はゼオライトのいかなる 触媒作用因子によって現われるかについてはいろいろの考察が行 なわれているが，著者らは前報に述べたよらにそれが交換カチオ ンの電気陰性度と密接な関係を有することを認めた ${ }^{2)}$ 。本報に扰 いても活性と交換カチオンの電気陰性度との間には図 4 に示され るよらに両者間には正の相関関係の存在することが認められた。 一方，3.2 で述べたよらにゼオライトの酸量と交換カチオンの電 気陰性度との間に直線関係が見いだされたので, 活性と酸量との

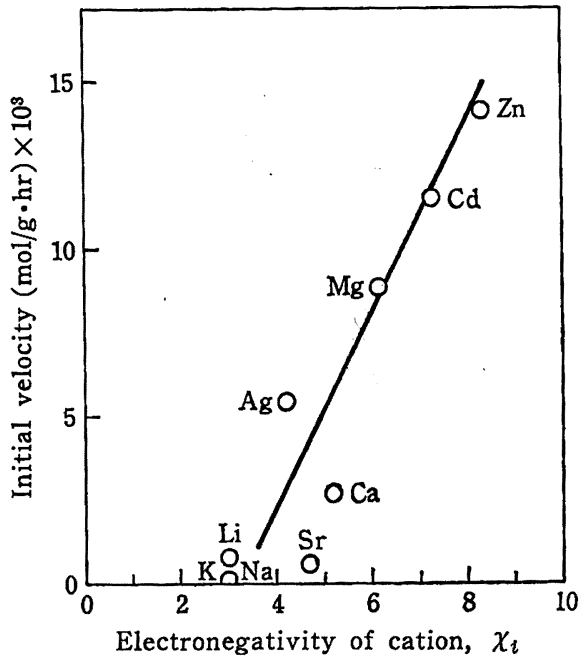

Fig. 4 Relation of catalytic activity of cation exchanged Zeolites A with electronegativity of cation

Reaction temperature $: 220^{\circ} \mathrm{C}, W / F: 1.27 \mathrm{~g} \cdot \mathrm{hr} / \mathrm{mol}$

Table 3 Distribution of product from ethylethylene oxide isomerization over Zeolite A cataysts

\begin{tabular}{|c|c|c|c|c|c|c|c|c|}
\hline \multirow{2}{*}{\multicolumn{2}{|c|}{ Catalyst }} & \multirow{2}{*}{$\begin{array}{c}\left.v_{0} \times 10^{s} b\right) \\
(\mathrm{mol} / \mathrm{g} \cdot \mathrm{hr})\end{array}$} & \multicolumn{5}{|c|}{ Product composition (mol\%) } & \multirow{2}{*}{$\frac{\mathrm{BA}+\mathrm{CA}_{t, c}}{\mathrm{MEK}}$} \\
\hline & & & $\mathrm{BA}^{a)}$ & $\mathrm{MEK}^{\alpha)}$ & $\mathrm{CA}_{t}{ }^{a)}$ & $C A_{c}^{a)}$ & $\left.\mathrm{NB}^{a}\right)$ & \\
\hline $\mathrm{Zn}$ & $5 A$ & 14.3 & 57.2 & 2.20 & 16. 7 & 15.1 & 8.74 & 40.5 \\
\hline $\mathrm{Cd}$ & $5 \mathrm{~A}$ & 12.3 & 63.6 & 2. 37 & 14.5 & 13. 9 & 6.38 & 38.5 \\
\hline $\mathbf{M g}$ & $5 \mathrm{~A}$ & 8. 10 & 60.2 & 2.09 & 18.5 & 15.5 & 3.59 & 45. 1 \\
\hline $\mathrm{Ca}$ & $5 \mathrm{~A}$ & 2.51 & 72.5 & 2.53 & 9. 39 & 9. 40 & 5.73 & 36.3 \\
\hline Sr & $5 \mathrm{~A}$ & 0.273 & 63.2 & 2.34 & 17.4 & 15.6 & 6. 35 & 39.0 \\
\hline $\mathbf{A g}$ & $5 \mathrm{~A}$ & 6.20 & 72.4 & 14.7 & 4. 69 & 4. 70 & 3.60 & 5.56 \\
\hline $\mathrm{Li}$ & $5 \mathrm{~A}$ & 0.340 & 55.0 & 2.11 & 19.1 & 17.5 & 7.00 & 43. 1 \\
\hline $\mathbf{K}$ & $5 A$ & 0 & - & - & - & - & - & - \\
\hline $\mathrm{Zn}_{\mathrm{n}}$ & $4 \mathrm{~A}$ & 14.8 & 58.3 & 2. 19 & 16.1 & 15.9 & 7.51 & 41. 3 \\
\hline $\mathrm{Mg}$ & $4 A$ & 8. 49 & 60.3 & 2. 31 & 17.6 & 16.9 & 3.00 & 41.0 \\
\hline $\mathrm{Ca}$ & $4 A$ & 2.56 & 69.4 & 2. 39 & 10.4 & 9.99 & 7.11 & 37.9 \\
\hline $4 A$ & & 0 & - & - & - & - & - & - \\
\hline
\end{tabular}

a) $\mathrm{BA}:$ Butyraldehyde, $\mathrm{MEK}$ : Ethyl methyl keton, $\mathrm{CA}_{t}:$ trans-Crotylalcohol, $\mathrm{CA}_{c}:$ cisCrotylalcohol, NB : $n$-Butylalcohol, Reaction temperature : $220^{\circ} \mathrm{C}, W / F: 1.27 \mathrm{~g} \cdot \mathrm{hr} / \mathrm{mol}$.

b) Initial velocity. 


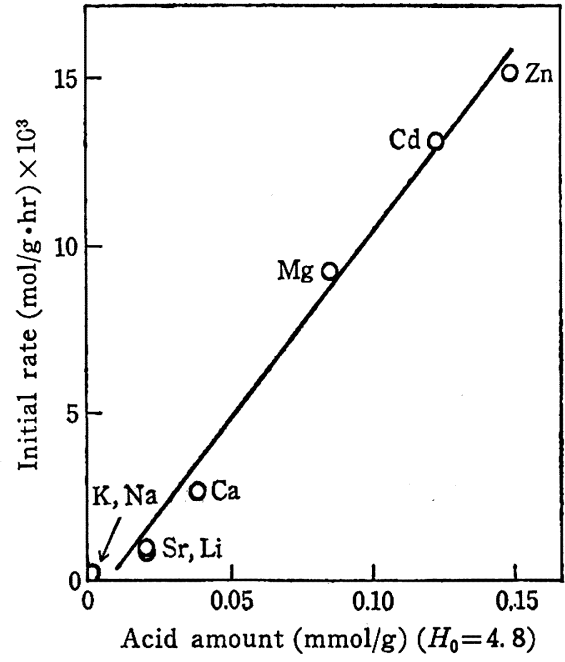

Fig. 5 Relation of catalytic activity of cation exchanged Zeolites $A$ with acid amount of Zeolites A

Reaction temperature : $220^{\circ} \mathrm{C}, W / F: 1.27 \mathrm{~g} \cdot \mathrm{hr} / \mathrm{mol}$

間飞る直線関係があることは容易に予想される。事実, 因 5 亿示 されるように直線関係が成立した。したがって，この事実は $\mathrm{A}$ 型 ゼオライト触媒上で起きるェチルェチレンオキシドの異性化反応 が交換カチオンにより生じた Brönsted 酸点により促進されると い53.4 の推定結果を支持しらる。

なお，カチオン交換率の活性㧍よび酸性質におよよ゙す影響を別 化調べた結果，交換率の増大とともに活性も酸量も增大するが， 交換率約 $80 \%$ 以上で活性はほぼ一定值を示し，その交換体特有 の值とみることができた。それてついての詳細は次報に報告す る。

\section{6 交換カチオンの生成物選択性入およばす影響}

以上に述べたよらに EEO の異性化活性はいろいろのカチオン 交換体に上り異なるが，それによる生成物組成は表 3 の上らな分 布を示す。生成物中の BA，CA は反応体分子の炭素一酸素結合の $\alpha$-開裂により生成し，MEK は $\beta$-開裂により生成するものと考 兄られる。そこで触媒の生成物組成に拉よぼす選択性の目安とし て $(\mathrm{BA}+\mathrm{CA}) / \mathrm{MEK}$ 比をとると, AgA を除いて，すべてのカチ
オン交换 $\mathrm{A}$ 型でオライトで約 40 であり，明らかに $\alpha$-開裂が传 先されていることがわかる。一方，著者らはいろいろの金属塩触

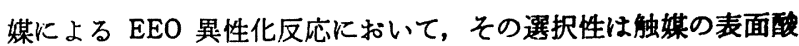
強度によりいちしるしく変化することを見いたしただす。しかし， A 型ゼオライト触媒ではカチオン交換によりその酸強度が变化す るにもかかわらず，その選択性は変化しない。これはすべてのA 型ゼオライトに共通の均一な結晶構造が選択性決定に大きな影䇾 を与えたためと考えられる。すなわち，反応関与する分子は大 部分ゼオライト内部表面の活性点(1) である Brönsted 酸点上飞吸 着し，転化，脱離するが，そのさい，分子はA型ぜオライト特有 の分子フルイ作用を受け，紐孔径より大きな分子は吸着も脱離も し克ないといら原理にしたがい，ケトンより分子径の小さいアル デヒドへの転化，脱離生成が有利となり生成物選択性が決定され る。

$\mathrm{AgA}$ が他と異なる選択性を示す理由は前に述べたように結晶 構造が一部破壊されているため，A型ゼオライト特有の分子フル イ効果を発揮できないためと思われる。AgA はまたほかの反応 に対してる特異な選択性を示すことが報告されている゙)のでよ り詳細な検討が必要であると思われる。

\section{8 異性化反応機構}

以上の結果から，異性化反応はつぎのよらな機構で進行するる のと推論される。すなわち，EEO はその酸素で触媒上の酸点K 四着する。そして電荷の不均化侄より酸素一炭素結合が開裂する が, その場合に, 当然より安定な第二カルガニウムイオンを形成 するよらに開裂するであらら。したがって下四のよらK $\alpha$-開裂 が優先される。そしてその開裂はA型ゼオライトの立体的要請に る答えている。

$\alpha$-開裂は， BA および CA を生成するが，転化のさい CA 㤌 $\mathrm{BA}$ より多く立体的汇固定されなければならないのでその是は少 なくなるのであろら。SrA，LiA のように活性点の酸強度が弱い 場合， $\beta$-開裂か促進されて MEK の生成が増大し（BA+CA)/ MEK 比が小さくなることが期待される15)のにるかかからず, そ の比が変化しないのは $\beta$-開裂によって MEK がゼオライト内部 表面で生成したとしてる，外部一脱離するさい，通過しなければ ならない細孔径が小さいため, 分子フルイ効果により阻止され， 実際, 気相中には注とんと存在しないためであろら。したがって,

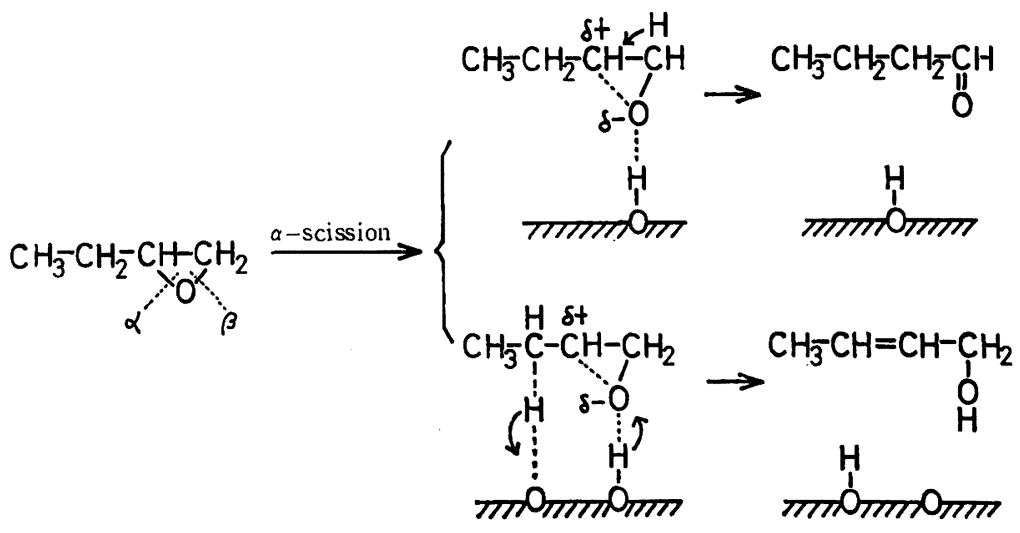

15）松本繁美，新田昌弘，青村和夫，日化，1973，2028; 日本 化学会北海道支部 1973 年冬期研究発表会講演要旨集, 3 B 05 .
16） ビオライトの外部表面積は内部表面栍の数パーセントにす ぎない.したがって外部表面上の活性点で反応する分子は きわめて少量であり，選択性には寄与しないと考えられる。 
全酸量の少ないそのような触媒の場合には $\alpha$-開裂もあまり促進 されていないから当然, 全反応速度も小さい（表 3)。

また EEO の異性化が逐次的あるいは可逆的に進行している場 合は反応途中の生成物分布をとってただちに EEO の $\alpha$-および $\boldsymbol{\beta}$-開裂の割合や異性化機構を推定することは危険である。そこで $\mathrm{ZnA}$ および $\mathrm{CaA}$ を触媒として $\mathrm{EEO}$ の異性化と同一反応条件で BA，MEK，CA および NB を拈の拈の単独で反応させたが，い ずれるまったく異性化を起こさなかった。したがって EEO の異 生化は本実験条件下では不可逆かつ並発的に進行し, 生战物組成 への逆反応および逐次反応の寄与は無視できることがわかった。

\section{4 結. 論}

いろいろのカチオンで交換した合成 $\mathrm{A}$ 型ぜオライトの触媒作用
を EEO の異性化反応について検討した結果, つぎのことがわか った。

1）異性化活性は交換カチオンの種類に依存し, 活性と触媒の 酸性 $\left(H_{0} \leqq+4.8\right.$ の全酸量) との間に比例関係がある。

2）交換カチオンの電気陰性度と酸量との間に正の相関閃係が ある。 $400^{\circ} \mathrm{C}$ 焼成 A 型ゼオライトの EEO 異性化活性点は Brönsted 酸点である。

3） EEO の異性化は不可逆かつ並発的に進行し，生成物避択 性はA 型ゼオライトの酸性質に無関係で，ゼオライト特有の分子 フルイ効果に依存する。

終りにX線回折の測定および解析にさいし多大の便宜を与えら れた東海大学教授石井次郎博士に感謝いたします。

(1973 年 4 月, 日本化学会第 28 春季年会発表)

\title{
Isomerization of Ethylethylene Oxide over Cation Exchanged Synthetic Zeolite A Catalyst ${ }^{\dagger}$
}

\author{
Masahiro Nitta, Shigemi Matsumoto and Kazuo Aomura \\ Laboratory of Analytical Chemistry, Faculty of Engineering, \\ Hokkaido University; Sapporo-shi 060 Japan
}

In order to elucidate the catalytic properties of cation exchanged zeolites $A$, the isomerization of ethylethylene oxide (EEO) was investigated in a flow system at atmospheric pressure and $220^{\circ} \mathrm{C}$. The reaction products were butyraldehyde(BA), ethyl methyl ketone(MEK), crotyl alcohol(CA) and $n$-butyl alcohol. The isomerization proceeded irreversibly and simaltaneouly. The ratio of $(\mathrm{BA}+\mathrm{CA})$ to $\mathrm{MEK}$ was about 40 regardless of the kinds of exchanged cation except $\mathrm{AgA}$, indicating that the $\alpha$-scission of EEO occured preferentially on all of the zeolites A. The catalytic activity and the acidic property depended upon the kinds of exchanged cation. The activity of zeolites $\mathrm{A}$ which were heat-treated at $400^{\circ} \mathrm{C}$ increased in the order of $\mathrm{ZnA}>\mathrm{CdA}>$ $\mathrm{MgA}>\mathrm{AgA}>\mathrm{CaA}>\mathrm{SrA}, \mathrm{LiA}>4 \mathrm{~A}, \mathrm{KA}=0$, and the acidity also agreed with this order. When the calcination temperature of zeolite $\mathrm{A}$ was in the range of 200 to $450^{\circ} \mathrm{C}$, the activity and the acidity were constant although both of them decreased at the higher temperature. Good correlations were found between the activity and the electronegativity of exchanged cation, and the acid amount $\left(H_{0} \leqq+4.8\right)$.

From the facts described above, it may be concluded that the isomerization of EEO on cation exchanged zeolites $A$ was catalyzed by the Brönsted acid sites and the moleculuar sieve action of zeolite $\mathrm{A}$ is responsible for selectivity of products.

$\dagger$ Catalytic Properties of Synthetic Zeolite A Type. II. 